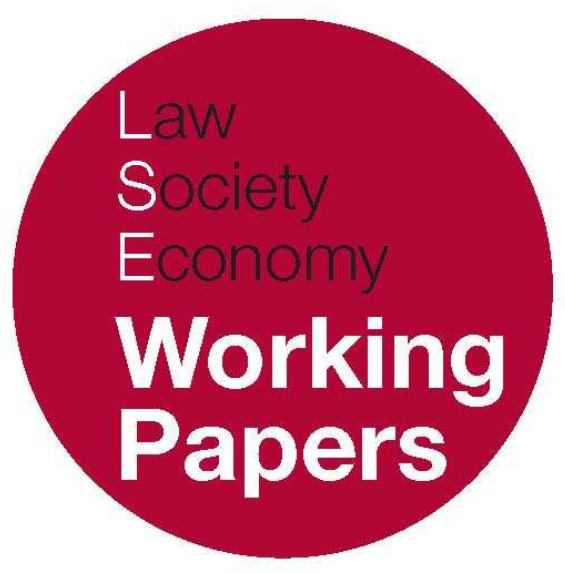

\title{
The Future of Communications Regulation after Ofcom's Pay-TV Consultation
}

\author{
Pablo Ibáñez Colomo
}

LSE Law, Society and Economy Working Papers 23/2010

London School of Economics and Political Science

Law Department

This paper can be downloaded without charge from LSE Law, Society and Economy Working Papers at: www.lse.ac.uk/collections/law/wps/wps.htm and the Social Sciences Research Network electronic library at: http://ssrn.com/abstract=1719655.

(C) Pablo Ibáñez Colomo. Users may download and/or print one copy to facilitate their private study or for non-commercial research. Users may not engage in further distribution of this material or use it for any profit-making activities or any other form of commercial gain. 


\title{
The Future of Communications Regulation after Ofcom's Pay-TV Consultation
}

\author{
Pablo Ibáñez Colomo *
}

\begin{abstract}
The present article examines the implications of Ofcom's pay-TV consultation for the future of communications regulation. It is submitted, first, that the authority's approach departs from what appeared to be well-established principles in the relevant sector-specific instruments. While ex ante intervention only seemed justified in presence of structural obstacles to effective competition, the logic underpinning the pay-TV consultation suggests that intervention may be justified whenever the regulator expects it to benefit consumers and competition. Similarly, Ofcom does not feel bound by the limits that would derive from competition law. More generally, the article examines the extent to which the broader technological and regulatory context surrounding the pay-TV consultation is relevant to explain the position taken by the authority.
\end{abstract}

\section{INTRODUCTION}

On 31 March 2010, Ofcom issued a statement putting an end to its three-year investigation into the British wholesale 'pay-TV' markets, which have been dominated by BSkyB for more than 15 years. ${ }^{1}$ The unusually lengthy proceedings are likely to extend in time, as BSkyB seems unwilling to conform to the regulator's wishes and has appealed its decision before the Competition Appeals Tribunal. ${ }^{2}$

\footnotetext{
* Law Department, London School of Economics and Political Science. E-mail: p.ibanezcolomo@1se.ac.uk.

1 Ofcom, 'Pay TV Statement' (31 March 2010), at http://www.ofcom.org.uk/tv/paytv/. The decision to start a market investigation was made public on 20 March 2007.

2 See J. Darroch, 'Sky Planning Three-Pronged Assault on Ofcom' Guardian (4 May 2010). In spite of the decision to appeal Ofcom's decision, BSkyB has reached an agreement with its competitors BT, Virgin
} 
Ofcom's decision comes at a turning point in convergent communications sectors (ie television and telecommunications industries). With the increase in broadband speeds - and with the prospects of even more substantial increases in this sense as a result of the use of fibre in the local telecommunications infrastructure (ie the 'local loop')—-telecommunications operators, such as BT, can now combine voice telephony (fixed and mobile) and broadband Internet services with multichannel television, ${ }^{3}$ to offer the so-called 'triple play' and 'quadruple play' bundles. ${ }^{4}$ In reaction to these developments and prospects, multichannel providers such as BSkyB (or Canal+ in France) have merged with broadband Internet providers so that they can compete with incumbent telecommunications operators across the whole range of convergent services. ${ }^{5}$

For all of the surrounding controversy, the essence of Ofcom's intervention in wholesale pay-TV markets is easy to grasp. The contentious decision seeks to fill a perceived gap in regulation. Because 'television content' was left outside of the scope ratione materiae of the EU Regulatory Framework for electronic communications adopted in 2002 (hereinafter, the 'EU Regulatory Framework'), ${ }^{6}$ access claims to television channels by BSkyB's competitors could only be addressed through competition law, which sets substantially higher standards of intervention.

Thus, Ofcom's decision reacts to this regulatory reality by requiring for premium sports channels operated by BSkyB (Sky Sports 1 and Sky Sports 2) the same access obligations currently applying to the 'local loop' owned by BT. ${ }^{7}$ While

Media and Top Up TV for the supply of its premium sports channels. See 'BSkyB Reaches Agreement at the CAT' (29 April 2010), at http:/ / corporate.sky.com.

3 The expression 'multichannel television' refers to a bundle of television channels providing significantly more channels than those typically via analogue terrestrial television (ie if the typical terrestrial analogue offer is limited to five or six channels, multichannel television services bundle, at least, around 20 channels). The expression therefore includes services available via digital terrestrial television ('DTT'), analogue, and digital cable and satellite as well as broadband Internet (IPTV). Ofcom gives the same meaning to the notion of 'multichannel television' in its assessment of the progress in the take-up of digital television services. See http://www.ofcom.org.uk as well as the statistics provided below, n 17.

4 'Triple play' services typically combine fixed telephony, broadband Internet, and multichannel television. A 'quadruple play' services features, in addition, mobile telephony services. The remainder of the article will refer to 'triple play' as a shorthand for both bundles.

5 In 2005, the OFT cleared the acquisition of the broadband Internet provider Easynet by BSkyB (see OFT Decision of 30 December 2005, Anticipated Acquisition by BSkyB Broadband Services Limited of Easynet group plc). Likewise, the European Commission did not object to the acquisition of the broadband Internet provider Télé2 by SFR, a telecommunications operator controlled by Vivendi (which is, in turn, Canal+'s parent company) in 2007 (see European Commission Decision of 18 July 2007 in Case COMP/M.4504, SFR/Télé2).

${ }^{6}$ See in particular Directive 2002/21/EC of the European Parliament and the Council on a Common Regulatory Framework for Electronic Communications Networks and Services, OJ (2002), L 108/33 ('Framework Directive'). Article 2(c) of the Directive excludes from the scope of the notion of 'electronic communications services' (and therefore from the scope of the EU Regulatory Framework) 'content transmitted using electronic communications networks and services'.

7 Previous consultation documents had contemplated extending wholesale access obligations to premium film channels (Sky Movies). See in particular Ofcom, 'Pay Television Consultation - Access to Premium Content' (30 September 2008), at http://www.ofcom.org.uk/tv/paytv/ (hereinafter, the 'Second Consultation Document'). Questions related with the functioning of premium film-related markets will be finally addressed by means of a submission to the Competition Commission. See Ofcom, Premium 
the decision does not go as far as to require the 'functional separation' of BSkyB's wholesale and retail branches, ${ }^{8}$ Ofcom mandates fair, reasonable, and nondiscriminatory ('FRAND') wholesale access to the said premium channels on such terms that competition at the retail level can emerge and be sustained. ${ }^{?}$

The purpose of this piece is not to examine the details of the pay-TV consultation. ${ }^{10}$ Rather, it seeks to identify the major implications of Ofcom's approach for the future of communications regulation. The three sections that follow this introduction explain why the decision marks a shift away from the principles that have governed the sector in the past decade.

Following the adoption of the EU Regulatory Framework, it seemed undisputed that ex ante obligations in the communications sector were only justified in those segments of the value chain with structural obstacles to effective competition. As shown in Section 2 below, Ofcom has disregarded this principle in the pay-TV consultation, assuming instead that regulators are entitled to finetune broadcasting markets whenever they believe they can improve the conditions of competition therein.

Ofcom claims that it is promoting 'fair and effective competition' by requiring $\mathrm{BSkyB}$ to share its competitive advantages with its downstream rivals. In this regard, Section 3 notes that Ofcom does not feel constrained by the boundaries that competition law precedents would impose on regulatory action. It is submitted that Ofcom does not identify clear or practicable criteria that would allow to define in advance what 'fair and effective competition' is.

Finally, the present piece examines the economic and regulatory context surrounding the pay-TV consultation in an attempt to make sense of Ofcom's decision. It is apparent that technological evolution is making the regulation of convergent markets increasingly difficult. From this perspective, Ofcom's consultation may be interpreted as a move to preserve previous policy choices (and in particular, requiring the incumbent telecommunications operator to share its infrastructure) in a changing environment.

Pay TV Movies - Market Investigation Reference to the Competition Commission' (4 August 2010), at http://www.ofcom.org.uk/tv/paytv/.

8 The expression 'functional separation' refers to a regulatory remedy whereby a company (typically, a vertically-integrated one) is required by the authority to set up an autonomous subsidiary for some of its activities (generally as a reaction to concerns with the ability and the incentive of the company to discriminate against its upstream or downstream competitors). The original submission from BT, Setanta, Top-Up TV, and Virgin Media pled for the separation of BSkyB's wholesale and retail branches along these lines. See the 'Submission to Ofcom on the Need for a Market iInvestigation into the Pay TV Industry' (3 July 2007), at http://www.ofcom.org.uk/tv/paytv/.

9 This means, in practice, that wholesale charges are calculated to ensure that a 'reasonably efficient retailer' (ie not necessarily as efficient as BSkyB) can profitably offer these channels.

10 See in particular M. Cave, 'The Proposed Wholesale Must Offer Remedy' (September 2009), at http://www.ofcom.org.uk/tv/paytv/. For a detailed analysis of the consultation, see also B. Van Rompuy, 'Fair Access to Exclusive Sports Rights Still a Long Shot in UK Pay Television Market' (2009) 14 Communications Law 109; and P. Ibáñez Colomo, 'Ofcom's Proposal to Regulate Access to Premium Television Content: Some Thoughts’ (EUI LAW Working Paper No. 2009/3), at www.ssrn.com. 


\title{
2. WHEN IS EX ANTE INTERVENTION JUSTIFIED IN COMMUNICATIONS MARKETS?
}

\author{
Principles OF EX ANTE INTERVENTION UNDER THE EU REgUlatory \\ FRAMEWORK VS OFCOM'S DECISION
}

The rationale underpinning the EU Regulatory Framework for electronic communications is that competition is the best means to promote consumer welfare and innovation in the communications sector. Thus, in those segments of the value chain where there are no structural obstacles for rivalry to emerge, free market entry (ie entry unconstrained by regulatory barriers) is favoured over any other form of ex ante regulation replicating the workings of an effectively competitive market (such as price controls or quality benchmarks).

The same philosophy informs intervention in those wholesale segments of the value chain in which ex ante regulation is deemed necessary. Instead of mimicking the outcome of effectively competitive markets in terms of price, choice and innovation, the EU Regulatory Framework expresses a preference for regulatory approaches that mimic their structure. This is typically achieved by means of wholesale access and non-discrimination obligations devised to promote and sustain market entry at the retail level.

The adoption of ex ante measures is subject to strict conditions under the EU Regulatory Framework. First, it is necessary for the national regulator to provide evidence of 'high and non-transitory barriers to entry' of a 'structural, legal or regulatory nature' in the relevant wholesale market. ${ }^{11}$ This first condition is an attempt to single out non-duplicable segments of the value chain (ie those segments with natural and / or a network monopoly features). The 2007 Recommendation on relevant markets shows that the 'local loop' is the major focus of regulatory attention. ${ }^{12}$ In addition, it is necessary for the national authority to show that the market in question 'does not tend towards effective competition within the relevant time horizon', 13 and that the 'application of competition law alone would not adequately address the market failure(s) concerned'. ${ }^{14}$

Among markets that are presumed to fulfil these three criteria, two of them are related with wholesale access to the 'local loop' (ie 'local loop unbundling', or 'market 4' in the 2007 Recommendation, and 'wholesale bitstream access', or

\footnotetext{
11 'Commission Recommendation of 17 December 2007 on Relevant Product and Service Markets Within the Electronic Communications Sector Susceptible to Ex Ante Regulation in Accordance with Directive 2002/21/EC of the European Parliament and of the Council on a Common Regulatory Framework for Electronic Communications Networks and Services', OJ (2007) L 344/65 (hereinafter, the '2007 Recommendation'), para 5.

12 Of the seven markets identified by the European Commission in the 2007 Recommendation, ibid, there are five markets that are directly related with the natural monopoly features of the local loop (and its impact on end-consumers, competing operators for interconnection and wholesale access purposes). 132007 Recommendation, n 11 above, para 12.

14 ibid, para 13.
} 
'market 5'). The practical implementation of the EU Regulatory Framework confirms that access obligations are imposed in these markets so long as their withdrawal would result in the foreclosure of new entrants at the retail level. Accordingly, wholesale access obligations are no longer justified where new entrants have alternative sources of supply. For instance, as new entrants in communications markets rely increasingly on 'local loop unbundling' (ie 'market 4'), and less on 'wholesale bitstream access' to the 'local loop' ('market 5'); the withdrawal of regulatory obligations in the latter market no longer leads to retail foreclosure, and therefore ex ante intervention is no longer justified. This logic explains Ofcom's decision to deregulate 'market 5' in some areas of the UK in 2007.15

Regarding the pay-TV consultation, one would have expected Ofcom to examine whether the markets for premium television channels are comparable to the candidates for ex ante intervention in the 2007 Recommendation in which similar access issues arise.

Such an analysis would have made it apparent that premium television cannot be equated with 'local loop'-related markets in any way. Premium sports and cinema channels are clearly not a necessary input - quantitatively or qualitatively for a television or broadband Internet operator to compete with BSkyB at the retail level. As a consequence, it cannot be expected that lack of access to this type of content will lead to downstream foreclosure.

A comparative overview of the market conditions in several Member States indeed shows that the number of households having access to multichannel television services (alone or as part of a 'triple play' bundle) exceeds by far the number of subscribers to premium television channels.

Premium channels are virtually marginal in those countries (Benelux, Germany) where multichannel television was first introduced (via cable) and had reached quasi-universal penetration ('cable countries') already in the early 1990s. ${ }^{16}$ Market evolution in 'terrestrial countries', where multichannel television was introduced later in time (primarily via satellite), dismisses as well the idea that access to premium content is necessary in some way to compete at the retail level. In the UK, the DTT service Freeview is as popular as a multichannel offer as satellite, even though the share of premium television subscribers via DTT is minimal. ${ }^{17}$ In France, subscriptions to 'triple play' bundles have increased at a

\footnotetext{
${ }^{15}$ See Ofcom, 'Review of the Wholesale Broadband Access Markets - Final Statement and Notification' (May 2008), at www.ofcom.org.uk. See also O. Bringer and K. Schumm, 'Revolution or Evolution in Telecoms? Sub-National Markets in Sector-Specific Regulation When Competition Develops Unevenly' (2008) 2 Competition Policy Newsletter 25.

${ }^{16}$ For instance, Sky Deutschland (formerly Premiere) has around two million subscribers to its premium TV services in a country that counts around 35 million TV households. Historically, figures have remained similarly low in the Benelux countries. For a summary and a discussion of these figures, see Sky Submission, 'Penetration of Premium Pay TV Services in Other European Countries', at http://www.ofcom.org.uk/tv/paytv/.

17 According to the last version of the Digital Progress Report issued by Ofcom when writing this piece (1st Quarter 2010), 39.8 per cent of households in the UK relied primarily on Freeview for the reception
} 
spectacular rate from the mid-2000s onwards. During this period, the subscription rates to premium television channels (Canal + ) have remained almost unaltered. ${ }^{18}$

In reality, Ofcom never claimed - let alone established - in its consultation documents that BSkyB's wholesale access to premium television channels is necessary to avoid downstream foreclosure. For the regulatory authority it was sufficient to note, first, the 'importance' of this type of content for retail competition, ${ }^{19}$ and second, to stress the expected consumer benefit that would result from regulatory intervention. ${ }^{20}$ In other words, Ofcom considers that an important competitive advantage may as such justify access obligations.

As can be seen, the logic of Ofcom's proposal represents a shift away from the principles of ex ante intervention under the EU Regulatory Framework. Access obligations in the latter instrument were never justified merely on grounds that increased rivalry can be expected to benefit consumers and increase retail rivalry. More modestly, they constitute a means to achieve effective competition in those segments of the value chain where entry cannot be reasonably expected to emerge absent $e x$ ante intervention.

\section{UNINTENDED EFFECTS OF EX ANTE INTERVENTION}

Perhaps the single most striking feature of the pay-TV consultation is that Ofcom never examined the unintended effects of its decision in neighbouring markets or the communications sector at large. One of the consequences of mandating shared access to BSkyB's premium television channels is that a powerful source of competitive pressure on the incumbent telecommunications operator, BT, would disappear. Moreover, Ofcom's proposed intervention would contribute to the commoditisation of broadband Internet offers, ie to a situation in which broadband operators compete essentially on price and lack the ability to differentiate their products on the basis of their quality.

Given the economic features of electronic communications markets, it is surprising to see Ofcom favouring the creation of a level playing field where prices are the primary dimension of competition, and new entrants are unable to differentiate their offers from those of the incumbent. The early experience of deregulation in the US shows how difficult it is to achieve effective competition on a lasting basis where retail offers are commoditised. ${ }^{21}$ In such a context, new

of television services. By contrast, 41.3 per cent of households relied primarily on satellite multichannel television and 12.9 per cent on cable. See Ofcom, 'The Communications Market: Digital Progress Report - Digital TV Q4 2010' (2 July 2010), at www.ofcom.org.uk. According to the same source, only two per cent of viewers relying primarily on DTT multichannel television subscribed to a premium television offer, compared to 36.2 per cent who relied primarily on satellite.

${ }^{18}$ For an overview of these figures, see La Lettre de l'Autorité (No 62, September/October 2008), at www.arcep.fr.

${ }_{19}$ Ofcom, 'Second Consultation Document', n 7 above, 28 et seq.

20 ibid, 150 et seq.

${ }^{21}$ R.W. Crandall, 'The Remedy for the 'Bottleneck Monopoly' in Telecom: Isolate It, Share It, or Ignore It?' (2005) 72 University of Chicago Law Review 3; and A. Oldale and A. Jorge Padilla, 'From State Monopoly 
entrants in electronic communications markets are typically forced to attract subscribers through advertising campaigns and price decreases, and this, offering essentially the same services of the incumbent. ${ }^{22}$

It would seem that preserving the ability of a new entrant to exploit a competitive advantage at will is the logical means to preserve its incentives to invest and, by the same token, to promote effective competition in communications markets. This is all the more important in the context of a transition towards the use of fibre in the 'local loop'. If the long-run aim of communications regulation is to achieve facilities-based competition through shared used of ducts and civil engineering works, ${ }^{23}$ there is probably not a better incentive for a new entrant to roll out alternative infrastructure than the ability to secure a customer base through the exploitation of premium television content.

Ofcom did not consider these crucial issues in its assessment. Originally, Ofcom did not even assess whether lack of access to premium television channels would adversely affect competition at the retail level or whether it would, on the contrary, enhance it. Instead, the regulatory authority simply examined directly how mandated access to BSkyB's premium television channels would benefit consumers. ${ }^{24}$ When prompted by participants in the consultation, Ofcom identified several retail markets for premium television content that matched exactly the wholesale markets for premium sports and premium cinema channels that had been identified in previous documents. ${ }^{25}$ In so doing, it did little more than come to the tautological conclusion that the quasi-monopolistic provider of premium television channels at the wholesale level is a dominant provider of these channels at the retail level.

The narrow definition of retail markets defended in the pay-TV consultation did not reflect the reality of competition among broadband operators and providers of multichannel television services. ${ }^{26}$ In particular, Ofcom crucially ignored that BT and Virgin Media dominate British broadband Internet markets with a joint market share of almost 50 per cent (BSkyB's share being lower) and, therefore, that they are able in principle (and to the extent that premium television

\footnotetext{
to the 'Investment Ladder': Competition Policy and the NRF' in Swedish Competition Authority' in The Pros and Cons of Antitrust in Deregulated Markets (Stockholm: 2004), at

http://www.kkv.se/upload/filer/trycksaker/rapporter/pros\&cons/rap_pros_and_cons_pricediscriminat ion.pdf.

${ }^{22}$ For an exhaustive empirical overview of the US case, see R.W. Crandall, Competition and Chaos - US Telecommunications after the 1996 Telecom Act (Washington DC: Brookings Institution Press, 2005).

${ }^{23}$ See Ofcom, 'Review of the Wholesale Local Access Market - Consultation on Market Definition, Market Power Determinations and Remedies' (23 March 2010), at www.ofcom.org.uk.

${ }^{24}$ See $n 20$ above.

${ }_{25}$ Ofcom, 'Pay TV Phase Three Document' (26 June 2009), at http://www.ofcom.org.uk/tv/paytv/, 99 et seq.

${ }^{26}$ In fact, multichannel operators like BSkyB and Virgin Media do not compete by offering a single channel or stand-alone bundles of premium channels. In reality, these operators compete by offering different multichannel combinations, and premium television channels are only offered as an upgrade. Broadband Internet operators, on the other hand, compete across the whole range of 'triple play' services, and not for the provision of a specific type of television service.
} 
content is not necessary to provide 'triple play' services) to deploy a range of counterstrategies and thus preserve its customers or to attract new ones. ${ }^{27}$

In fact, the implicit view that transpires from the pay-TV consultation is that Ofcom is entitled to influence $e x$ ante the evolution of communications markets and alter the conditions of competition therein so as to favour a particular outcome (eg a level playing field in which price-based competition between homogeneous services is the norm) over others (eg competition between providers offering differentiated services).

This idea contrasts with Ofcom's self-declared bias against intervention. The EU Regulatory Framework - later implemented in the 2003 Communications Act - reflects a different approach to regulation that avoids fine-tuning markets and picking a particular outcome or architecture. In this regard, the EU Regulatory Framework crucially acknowledges that regulators are generally ill-suited to predict the evolution of markets in innovation-driven industries and that intervention may cause unintended effects that must be taken into account.

\section{WHAT IS ‘FAIR AND EFFECTIVE’ COMPETITION?}

The legal basis for Ofcom's intervention is Section 316 of the 2003 Communications Act (hereinafter 'Section 316'), which empowers the regulatory authority to preserve 'fair and effective competition' in broadcasting markets. ${ }^{28}$

Section 316 had never been relied upon for similar large-scale market interventions. ${ }^{29}$ As a consequence, there are reasons to question at the outset whether it is appropriate to set up a far-reaching regulatory regime when the purpose and boundaries of the relevant legal basis remain unexplored up (and particularly so when the authority construes the legal basis in such a way that it contradicts competition law and the EU Regulatory Framework). ${ }^{30}$ In addition, it is not yet obvious to grasp how Ofcom - and BSkyB's competitors supporting intervention - interprets this provision.

\footnotetext{
27 On BT's and Virgin Media's market shares, see the information at http://www.ofcom.org.uk. According to the Telecommunications Market Data Update corresponding to the fourth quarter of 2009 issued by Ofcom in May 2010, subscribers to BT and Virgin Media amounted to eight point six million, for a total of around 18 million subscribers.

${ }^{28}$ Pursuant to Section 316(1) of the 2003 Communications Act: 'The regulatory regime for every licensed service includes the conditions (if any) that OFCOM consider appropriate for ensuring fair and effective competition in the provision of licensed services or of connected services.'

${ }^{29}$ In the different consultation documents, Ofcom does not refer to any precedents in support of its interpretation of Section 316, and chooses instead to rely on preparatory works of the 2003 Communications Act. Previously, Section 316 had been used to adopt different codes of practice, such as the Code on Access to Electronic Programme Guides and the Code on the Cross-Promotion of Programmes.

30 For an extensive analysis of this question, see P. Ibáñez Colomo, 'Ofcom's Proposal to Regulate Access to Premium Television Content: Some Thoughts' (EUI LAW Working Paper No. 2009/3), at www.ssrn.com.
} 
One may understand Ofcom's interpretation of Section 316 in two alternative ways:

- On the one hand, one may understand that ex ante intervention is justified insofar as BSkyB's conduct is anticompetitive. From this perspective, Section 316 would fulfil the same function as competition law, the application of which is triggered by a prohibited line of behaviour (a unilaterally abusive practice, an agreement, or a merger).

- On the other hand, several passages in the different consultation documents issued by Ofcom suggest that the authority is concerned about the structural features of premium television markets as such. From this perspective, Section 316 would allow Ofcom to fine-tune market structures so that 'fair and effective competition' is promoted and preserved. This understanding of Section 316 would bring it closer to market investigation references to the Competition Commission, ${ }^{31}$ and to the EU Regulatory Framework, in which cases the trigger for intervention is structural, as opposed to behavioural.

In either case, Ofcom's position would remain controversial and would have important implications for the future of communications regulation. First, if Section 316 is to become a form of 'sector-specific competition law', one would reasonably expect it to be construed and interpreted along the lines of general competition law provisions. Secondly, a finding that the features of a given market preclude 'fair and effective competition' simply because they do not fit with the market structure preconceived by the regulator is a source of concern.

\section{HOW MANY STANDARDS OF ANTICOMPETITIVE CONDUCT?}

If intervention under Section 316 is based on the idea that BSkyB's behaviour is anticompetitive, turning to competition law precedents governing refusals to supply would have been the logical step for Ofcom to take.

One of the most fundamental and undisputed principles under Article 102 TFEU (and its national equivalents) is that a dominant company can only be forced to deal with its competitors in 'exceptional circumstances'. A constant line

\footnotetext{
${ }^{31}$ Pursuant to Section 134 of the 2002 Enterprise Act, the OFT or regulatory authorities such as Ofcom may require the Competition Commission to determine 'whether any feature, or combination of features, of each relevant market prevents, restricts or distorts competition in connection with the supply or acquisition of goods or services in the United Kingdom or a part of the United Kingdom' and may as a result propose remedial action. On this question, see in particular Competition Commission, 'Guidelines on Market Investigation References' (June 2003); OFT, 'Market Investigation References: Guidance About the Making of References Under Part 4 of the Enterprise Act' (2002). See also P.A. Geroski, 'The UK Market Inquiry Regime' in B.Hawk (ed), Annual Proceedings of the Fordham Corporate Law Institute (2004) (New York: Juris Publishing, 2005).
} 
of case law, crystallised in the Guidance Paper issued in 2008 by the European Commission makes it clear that mandating shared access to an input under Article 102 TFEU requires at the very least evidence (i) of the indispensability of the input in question for rivals to compete in a neighbouring market and (ii) of the elimination of all competition therein. ${ }^{32}$ When intellectual property rights are involved, it is in addition necessary to show that a refusal to deal prevents the emergence of a 'new product. .33

The reasons for such a restrictive stance on refusals to deal are relatively straightforward and were lucidly exposed by A.G. Jacobs in his opinion in the Bronner case. ${ }^{34}$ A.G. Jacobs pointed to the need to preserve the competitive process, which would be endangered if the ex ante incentives to invest and outperform one's rivals were undermined by an overly generous stance on refusals to deal. The relevance of these concerns became in fact apparent in the context of Ofcom's consultation. 35

Ofcom did not interpret Section 316 along the lines of competition law. According to the regulator, Section 316 would support the imposition of access obligations even if there is no evidence of the indispensability of the premium television channels - or, for that matter, of the elimination of competition. Interestingly, Ofcom made explicit some of the reasons behind its choice. In the Second Consultation Document, issued in September 2008, the regulator acknowledged that it would not be possible to devise a regulatory regime supporting inefficient entry under competition law. 36

There are several reasons why it would be inappropriate to endorse simultaneously two different standards for the assessment of anticompetitive conduct. The first reason why a 'double jeopardy' in electronic communications

\footnotetext{
32 See in particular Case C-7/97, Oscar Bronner GmbH \& Co KG. Mediaprint Zeitungs- und Zeitschriftenverlag [1998] ECR I-7791; Case C-241/91 P and C-242/91 P, RTE and ITP v Commission [1995] ECR I-743.

33 In addition to Magill, see in particular the IMS Health and Microsoft sagas: Case C-418/01, IMS Health GmbH \& Co. OHG v NDC Health GmbH \& Co. KG [2004] ECR I-5039; T-184/01 R, IMS Health v Commission [2001] ECR II-2349; Commission Decision of 24 March 2004, Microsoft Corporation OJ (2007) L 32/23; and Case T-201/04, Microsoft v Commission [2004] ECR II-3601.

34 Opinion of AG Jacobs in Case C-7/97, n 32 above, para 57: '[...] the justification in terms of competition policy for interfering with a dominant undertaking's freedom to contract often requires a careful balancing of conflicting considerations. In the long term it is generally pro-competitive and in the interest of consumers to allow a company to retain for its own use facilities which it has developed for the purpose of its business. [...] Moreover, the incentive for a dominant undertaking to invest in efficient facilities would be reduced if its competitors were, upon request, able to share the benefits. Thus the mere fact that by retaining a facility for its own use a dominant undertaking retains an advantage over a competitor cannot justify requiring access to it'.

35 Ofcom never disputed that BSkyB's prominence in the wholesale markets for premium content was a result of the risks it took over the years. Ofcom's position is based on the idea that the benefits from intervention outweigh the detrimental impact on the incentives to invest in content and to innovate. See in this sense Ofcom, n 1 above, 593 et seq (Impact of the Remedy).

${ }^{36}$ See eg Ofcom, 'Second Consultation Document', n 7 above, 180 et seq: 'One of the potential reasons we identified for Sky's lack of incentive to supply was possible differences in efficiency between Sky and other retailers. If that were the case, an abuse might well not have taken place, but the negative impact on competition and consumers that we have identified would still exist. If we were to rely on our powers under CA98, we would not be able to address this competition problem absent an actual finding of anticompetitive behaviour.'
} 
would be problematic has to do with the unfettered discretion Ofcom would enjoy. If a given line of conduct were not easily caught by competition law, Ofcom would still have the chance to circumvent these limits by construing Section 316 in such a way that it fits with its preferred outcome. This risk is all the more important if one considers, as mentioned above, that Section 316 is virtually unexplored as a provision (at least so for the purposes for which it is relied upon in the pay-TV consultation).

The second reason why it would be desirable to bring Section 316 in line with competition law principles has to do with the long enforcement history of the latter. Competition law principles, as they currently stand, reflect decades of evolution and, in a discipline informed by economics, an increased understanding of the complexity of commercial transactions. As a result, limits on administrative discretion imposed by existing competition law precedents are generally grounded on a solid economic rationale.

If Ofcom's interpretation of Section 316 ignored decades of evolution in competition law, there would be a risk that the regulator insists on some errors or fallacies that have long been dismissed. The different consultation documents issued by Ofcom provide some examples of outdated or intuitive biases that would no longer be found in a competition law decision.

For instance, the whole of the analysis by Ofcom is based on the idea that 'effective competition' and increased price-based rivalry at the retail level are one and the same thing. In this same vein, greater price-based rivalry at the retail level is assumed by Ofcom to yield benefits for consumers in the form of reduced prices and increased innovation. ${ }^{37}$

Competition law does not equate 'effective competition' and price-based rivalry in the marketplace. This is so, first, because there are some markets in which competition takes place 'for' the market and not 'within' the market. In such circumstances, an exclusive focus on the market structure would not be a reliable indicator of 'effective competition' or market power. ${ }^{38}$ More importantly, competition authorities are now careful not to protect rivalry at the expense of efficiency. In this sense, it is widely understood and undisputed that an exclusive focus on promoting (or preserving) fragmented market structures is likely to harm companies' incentives to compete without this resulting in tangible benefits for consumers. These ideas are reflected in the Guidance Paper issued in 2008 by the European Commission. ${ }^{39}$

Likewise, Ofcom assumes that increased price-based rivalry in the marketplace would enhance innovation and consumer benefit. If shared access to

\footnotetext{
${ }^{37}$ Ofcom, n 1 above, 390 et seq.

38 On the notion of 'bidding market', see P. Klemperer, 'Bidding Markets' (2007) 3(1) Journal of Competition Law and Economics 1. See also D. Spector, 'The Antitrust Economics of Bidding Markets: An Introduction' (2007) 2 Concurrences 23.

39 'Guidance on the Commission's Enforcement Priorities in Applying Article 82 of the EC Treaty to Abusive Exclusionary Conduct by Dominant Undertakings', OJ (2009) C 45/7 (hereinafter, the 'Guidance Paper'), in particular para 6.
} 
BSkyB's premium television channels is mandated, the argument goes, increased price-based competition would force companies to invest in innovative features and bundle combinations for the benefit of consumers. ${ }^{40}$ Decades of experience in the field of competition law dismiss the assumption that there is necessarily a linear and positive relationship between rivalry in a market and the innovation levels therein.

For instance, by assuming that price-based rivalry will force operators to innovate, Ofcom ignores the role of vertical restraints - and, in particular, of exclusive supply and exclusive distribution agreements - to tackle positive externalities (ie free-riding behaviour by competitors). In landmark rulings such as Société Technique Minière and Coditel II, the ECJ understood that vertical restraints granting exclusive rights to the supplier or the distributor of a given product / service may in fact be necessary to secure investments at the distribution level. ${ }^{41}$

In other words, and contrary to Ofcom's assumptions, the exploitation of a given input on an exclusive basis is in some markets a precondition for innovation and investments. Considering that exclusive dealing has always been a pervasive feature of the television industry, and this, at several levels of the value chain (think for instance of the fundamental role of exclusive licensing in the launch of satellite pay-TV systems in the early 1990s), one would have expected Ofcom to explain convincingly why the retail provision of premium television services is not one of these markets.

\section{HOW ARE THE TERMS OF 'FAIR AND EFFECTIVE’ COMPETITION DEFINED?}

It is unusual to see a regulatory authority describing the features of an ideal market and then taking measures to engineer the existing structure so that it fits with its vision of 'fair and effective' competition. One can think of at least two powerful reasons why this approach to address perceived market failures is problematic.

First of all, the history of competition law teaches that it is virtually impossible to conclude that a given line of behaviour is anticompetitive (and / or unfair) by its very nature (or, similarly, by examining the intent of the company). In many cases, it is necessary to turn to the context surrounding the behaviour in question before coming to a conclusion. In other words, the fact that a given market does not conform to visions of 'fair and effective' competition does not mean that some of its features need adjustment. In this regard, one would have expected Ofcom to examine the economic circumstances surrounding the observed anomalies before coming to a conclusion about the functioning of the relevant markets.

40 Ofcom, n 1 above, 426 et seq.

${ }^{41}$ In both cases, the European Court of Justice was ready to accept that a reduction in intra-brand competition could fall outside the scope of Article 101(1) TFEU in spite of its negative impact on prices. See Case 56/65, Société Technique Minière [1966] ECR 337; Case 262/81, Coditel SA, Compagnie générale pour la diffusion de la télévision, e.a. v Ciné-Vog Films SA e.a. [1982] ECR I-3381. 
The authority identified two anomalies in the functioning of pay-TV related markets:

- BSkyB's position of market power at the wholesale level (in fact, a quasimonopoly, according to Ofcom's definition of the relevant markets), and

- BSkyB's lack of incentive to supply its premium television channels to its competitors at the retail level. In other words, Ofcom assumes that in a competitive market the provider of premium television channels would supply to its downstream competitors.

Take the first of these alleged anomalies. A comparative overview of the evolution of the pay-TV segment in fact suggests that both (i) the wholesale markets for the supply of premium television channels and (ii) the upstream markets for the acquisition of premium television rights tend to be monopolised by a single company. In other words, BSkyB's quasi-monopoly position appears to be the only structure that can be maintained in the relevant markets. In the UK, competition between BSB and Sky in these two segments of the value chain collapsed in 1990, ie only a few months only after the launch of these services. The same pattern would be later observed in other European countries, including Germany, Italy, ${ }^{42}$ Spain,${ }^{43}$ and France. ${ }^{44}$

The first major consequence of this market feature is that there is nothing anomalous in BSkyB's position in the relevant wholesale markets. In fact, any attempt to introduce rivalry in the relevant wholesale markets is bound to fail in the medium to long-run. The recent fate of Setanta Sports, which collapsed even before its contract with the Premier League had come to an end, is a recent and telling example. 45

The second consequence of this trend is that competition in the relevant wholesale markets resembles more an instance in which competition takes place 'for' the market and not 'within' it. In this sense, it would seem that competition between providers does exist, but in a way that differs from the ideal scenario envisioned by Ofcom.

An analysis of the sector indeed shows that operators interested in providing premium television services compete with one another. However, they do not compete at the wholesale level (a segment that tends towards monopoly), but upstream in the value chain, ie they compete in the markets for the acquisition of the rights for premium sports and premium film content in the auctions regularly

${ }^{42}$ Commission Decision of 2 April 2003, Newscorp/Telepiù OJ (2004) L 110/73.

${ }^{43}$ Decision of the Council of Ministers of 29 November 2002, Sogecable/Canal Satélite Digital/Via Digital, BOE (2003), 12/1707.

44 'Lettre du ministre de l'économie, des finances et de l'industrie du 30 août 2006, aux conseils de la société Vivendi Universal, relative à une concentration dans le secteur de la télévision payante' (BOCCRF, No. 7 bis of 15 September 2006).

45 On Setanta's fate, see 'Setanta Goes off Air with Loss of More than 200 Jobs' Guardian (23 June 2009). 
conducted by sports leagues and film studios. ${ }^{46}$ Thus, the question of whether one of these markets is competitive depends not so much on the outcome of the auctions (which tend to be monopolised) but on the bidding process in the markets for the acquisition of the rights.

The evolution of competition in several Member States suggests that competition in the wholesale markets for the provision of premium television services indeed tends to evolve by abrupt leaps, as a direct consequence of the evolution of upstream acquisition markets. In Belgium, Germany, Italy, and Spain, the position of the incumbent pay-TV players in the relevant wholesale markets seemed as solid as BSkyB's. However, the entry of new operators in acquisition markets (including incumbent telecommunications and terrestrial operators) altered the landscape in a radical manner from one auction to another. In some of these countries (as in Belgium or Spain), new entry led to the exclusion of the incumbent pay-TV operator from acquisition markets (and the corresponding wholesale markets) and in others (paradoxical as it may seem) to regulatory changes protecting the position of this incumbent at the wholesale and the retail levels. ${ }^{47}$

Take now the second of the anomalies detected by Ofcom, ie the fact that BSkyB allegedly lacks an incentive to supply its channels to its downstream competitors. As the competition law analysis above shows, a company's refusal to deal and share its competitive advantages with its competitors is assumed to be pro-competitive except in 'exceptional circumstances'. The concrete analysis of the circumstances surrounding BSkyB's alleged refusal confirms this impression.

It was never disputed in the course of the consultation that BSkyB had invested heavily in the acquisition and the exploitation of television rights for premium content. Moreover, one should take into account the fundamental fact (which arguably explains alone the launch of the consultation) that BSkyB and its rivals compete across the whole range of communications services at the retail level. As pointed out above, BSkyB acquired a broadband Internet operator to compete for the provision of 'triple play' services with the incumbents BT and Virgin Media. As a consequence, it is not obvious to see why the refusal to share a competitive advantage with two strong players at the retail level would be unfair or anticompetitive. It is equally difficult to understand why Ofcom concludes that in an effectively competitive market BSkyB would share its channels with its downstream rivals.

The second reason why Ofcom's conclusions are problematic is because they open the door to arbitrariness in policymaking. If Ofcom's analysis and

\footnotetext{
${ }^{46}$ On the notion of 'bidding market', in which competition takes place 'for' the market, see references at n 38 above.

${ }^{47}$ For instance, when the new entrant Mediaset acquired some of the most valuable TV rights for premium sports content in 2006, the Italian Competition Authority adopted interim measures protecting the incumbent Sky Italia. For a discussion of this case, see P. Ibanez Colomo, 'Saving the Monopsony: Exclusivity, Innovation and Market Power in the Media Sector' (College of Europe Research Papers in Law, No. 7/2006), at http://www.coleurope.eu.
} 
conclusions are unpersuasive, this is primarily because they could be used to justify intervention always and in virtually any market. Because market power is pervasive and because companies often provide heterogeneous products or services relying on their competitive advantages (which they often refuse to share with their competitors), 'fair and effective competition' in the way described by Ofcom could in theory be promoted in virtually all sectors of the economy. Indeed, there seems to be always scope to introduce further price-based competition and to increase retail rivalry for the benefit of consumers.

For instance, the same effects as those identified by Ofcom could also be established if the holder of any patent were required to share its intellectual property with its competitors requesting access to it. Similar arguments could be used to ban, inter alia, selective distribution agreements (which are widely understood to be pro-competitive under competition law), in that they limit competition between retailers and lead to higher prices. ${ }^{48}$

While virtually any market can in theory be perfected, intervention under competition law and the EU Regulatory Framework is careful to require something more than establishing a position of market power and / or of the lack of incentive to supply to its competitors. In all cases, there is an additional behavioural and / or structural element that allows the authority to define with more precision and certainty the instances in which intervention may be justified (additional behavioural elements include, as seen above, the indispensability and the 'new product requirement' in refusal to supply cases examined under Article 102 TFEU; a paradigmatic example of a structural trigger is the 'three criteria test' under the EU Regulatory Framework).

\section{DEALING WITH INNOVATION IN A HEAVILY REGULATED ENVIRONMENT}

As noted above, there is something paradoxical in Ofcom's decision. By requiring BSkyB to grant access to its premium sports channels to all requesting third parties, the competitive pressure placed on the incumbent telecommunications operator, BT, will significantly diminish. ${ }^{49}$ To the extent that access to premium content is not necessary for an operator to provide multichannel and 'triple play' services, it is not obvious why Ofcom would intervene to alter the existing market conditions in such a way. After all, the EU Regulatory Framework was primarily

\footnotetext{
48 See in particular Case 26/76, Metro SB-Großmärkte GmbH \& Co. KG v Commission [1977] ECR 1875, para 21. See also $n 41$ above.

${ }_{49}^{4}$ If cable operators (later to merge into Virgin Media) have had access to BSkyB's premium channels for more than a decade prior to the consultation, similar efforts in this sense by BT had not met with success. See Ofcom, 'Second Consultation Document', n 7 above, 125-127.
} 
conceived to undermine the dominant position historically enjoyed by incumbent telecommunications operators.

The economic and regulatory context in which the pay-TV consultation took place provides insights that could be helpful in explaining Ofcom's move. The crucial factor in this sense seems to be that, as pointed out above, convergent communications sectors are facing a turning point, in the sense that operators compete across the whole range of 'triple play' services. What is more, the fibre upgrade of the 'last mile' of cable and telecommunications networks bringing broadband speeds up to $100 \mathrm{Mbit} / \mathrm{second}$ can only be expected to further spur this trend.

These commercial developments are a source of major challenges for regulators insofar as the EU Regulatory Framework is (because of its limited scope ratione materiae) unable to deal with them. As a consequence of fibre upgrades, on the one hand, access to the incumbent's infrastructure by new entrants becomes increasingly difficult to justify. Access to the traditional copper-pair local loop on a cost-oriented basis was (at least in part) justified insofar as the telecommunications infrastructure had been rolled out with public subsidies at a time when incumbent operators were shielded from competition by regulatory barriers to entry. ${ }^{50}$ None of these two conditions apply to fibre upgrades. As a result, it is unsurprising that some national regulatory authorities ('NRAs') have taken steps to lift, reduce, or alter regulatory burdens on incumbent operators. ${ }^{51}$ Even though the European Commission is willing to extend access obligations to fibre infrastructure, ${ }^{22}$ (as much as Ofcom), 53 it would seem that a solid rationale is a precondition for the extension of the legacy regime in this new context.

As soon as television content is introduced in the regulatory equation, on the other hand, the situation grows increasingly complex. It could now very well happen that a new entrant benefits more from the incumbent's infrastructure

\footnotetext{
50 These arguments are deemed relevant even when applying the line of case law on refusals to supply. This is at least the position expressed by the European Commission in its Guidance Paper, n 39 above, para 82: 'In certain specific cases, it may be clear that imposing an obligation to supply is manifestly not capable of having negative effects on the input owner's and/or other operators' incentives to invest and innovate upstream, whether ex ante or ex post. The Commission considers that this is particularly likely [...] where the upstream market position of the dominant undertaking has been developed under the protection of special or exclusive rights or has been financed by state resources. In such specific cases there is no reason for the Commission to deviate from its general enforcement standard of showing likely anti-competitive foreclosure, without considering whether the three circumstances referred to in paragraph 81 are present.'

51 A paradigmatic example is that of the so-called 'regulatory holidays' that the German government intended to grant to infrastructure upgrades undertaken by the incumbent telecommunications operator. See Case C-424/07, Commission v Germany [2009], nyr. Similarly, the intentions of the Spanish authority to relax the obligations regarding access to newly developed infrastructure initially met with the opposition of the ECJ. See Case ES/2008/805: Wholesale Broadband access ('WBA'), 26 December 2008), at http://ec.europa.eu/information_society/index_en.htm, until the regime initially proposed was amended. 52 See 'Draft Commission Recommendation of 24 June 2009 on Regulated Access to Next Generation Access Networks (NGA)', at http://ec.europa.eu/information_society/index_en.htm.

53 See Ofcom, 'Variation to and Exemption from BT's Undertakings Under the Enterprise Act 2002 Related to Fibre-to-the-Premises and Fibre Integrated Reception System' (23 March 2010), at http://www.ofcom.org.uk.
} 
upgrades than the latter's own retail arm (it cannot be excluded, for instance, that BSkyB takes the majority of subscribers to multichannel television services via fibre). This prospect (which is admittedly awkward) may be seen as a powerful reason to require new entrants to share their advantages with the incumbent. From a regulator's viewpoint, mandating access to all important competitive advantages enjoyed by actual or potential players has the virtue of being an effective means to justify and legitimise the perpetuation of access obligations on the incumbent. What is more, this seems to conform to a basic idea of 'regulatory symmetry', as BT defended during the pay-TV consultation. ${ }^{54}$

What the analysis of the relevant variables suggests, at the same time, is that such an incremental approach to regulation, which deals with emerging concerns on a piecemeal basis, is not an appropriate one in a fast-moving industry. Where the primary focus of the authority is to preserve and legitimise the market architecture originally created through regulation, there is a risk that new ad boc measures run counter to the original objectives of regulation (as explained above), or, more generally, that they are mutually incompatible. 55 If technological and market evolutions make it appear that some of the assumptions underpinning the original regulatory regime no longer hold true, as seems to be the case of the EU Regulatory Framework, a comprehensive approach that acknowledges the full complexity and the limits of the previous regime is to be preferred.

\section{CONCLUSIONS}

Ofcom's decision can be seen as a reaction to the changing technological and economic circumstances in communications markets. The rise of 'triple play' offers indeed makes it impossible to perpetuate the misguided assumption underlying the EU Regulatory Framework according to which the regulation of television services can be isolated from the regulation of voice telephony and broadband Internet.

What is remarkable in the pay-TV consultation is that Ofcom departed from the existing instruments for the regulation of communications markets, and this, from a legal and from a policy perspective.

\footnotetext{
${ }^{54}$ In fact, during the pay-TV consultation BT pled in favour of 'regulatory symmetry', ie of ensuring that BSkyB's competitive advantages are shared in the same way its infrastructure is shared. 'BT Challenges Sky's Dominance of Pay TV' The Independent (15 July 2008). In this article, the chief executive of BT Vision was reported as saying: 'There is a real problem in the regulatory regime in the converged market the rules that apply to telecoms and to pay TV are completely asymmetrical.'

55 Think for instance of the inherent contradiction that currently exists regarding the regulation of access to premium sports content. On the one hand, the application of EU competition law seeks to open the market for the acquisition of television rights, on the hope that competition is promoted in downstream markets and, on the other, Ofcom's proposal seeks to impose access remedies at the wholesale level with the same purpose.
} 
From a legal perspective, the authority does not feel bound by the constraints on intervention that would logically derive from competition law and the EU Regulatory Framework. Under either of the two regimes, shared access to an input may only be mandated by an authority under very strict conditions, which were not established in the context of the pay-TV consultation.

One of the most controversial features of Ofcom's approach is in fact the choice of Section 316 of the Communications Act, which had never been relied upon for similar purposes, as the legal basis to avoid these constraints. The way in which the substance of the provision has been construed is not any less controversial. It is not obvious to grasp how the regulator defines what 'fair and effective competition' is under Section 316. In fact, it would seem that Ofcom's analysis and conclusions would support intervention in virtually any market in which an undertaking enjoys a (non-indispensable) competitive advantage and a position of market power (which is to say in any market).

From a policy perspective, Ofcom's decision involves a shift in the authority's approach to regulation. Both the EU Regulatory Framework and the 2003 Communications Act were based on the idea that regulators are ill-suited to engineer and fine-tune markets. This is most clearly reflected in the bias against intervention of these two texts, as a consequence of which ex ante intervention is only deemed justified in presence of a narrow set of structural conditions defined in advance (and only for as long as these conditions are present in the market in question). Ofcom's position in the pay-TV consultation is a different one. It stems from the decision that ex ante intervention to alter the conditions of competition in pay-TV related markets is justified so long as the regulator can expect it to benefit consumers and to promote price-based rivalry.

This legal and policy shift is of particular importance if one considers that the limits ratione materiae of the EU Regulatory Framework will force national regulators to enact similar ad hoc measures in the coming years. In this context, the Competition Appeals Tribunal will be almost called to play a fundamental role in defining the future of communications regulation. 